\title{
Relationship of Childhood Idiopathic Nephrotic Syndrome with Asthma, Hypertension, Complement $\mathrm{C}_{3}$, Urinalysis
}

\author{
RANJIT RANJAN ROY ${ }^{1}$, MD. RAFIQUL ISLAM ${ }^{2}$, ABDUL MATIN $^{2}$, RITAKHAN $^{3}$, GOLAM MUINUDDI $^{4}$, \\ MD. HABIBUR RAHMAN ${ }^{4}$, MD. MOAZZAM HOSSAIN ${ }^{5}$
}

\begin{abstract}
A prospective observational study of 43 children with idiopathic nephrotic syndrome (INS) were selected randomly out of 480 children admitted with the disease at Bangabandhu Sheikh Mujib Medical University, Dhaka, Bangladesh from January 2003 to January 2005.

Aim of this study was to correlate the difference in frequency of atopic attack, hypertension, complement $c_{3}$ level and urinalysis in different types of Idiopathic nephrotic syndrome.

Result: Among 43 children with idiopathic nephrotic syndrome (INS), 24 children were steroid sensitive nephrotic syndrome (SSNS) and 19 children having steroid resistant nephrotic syndrome (SRNS) cases, of SSNS group 13 were infrequent relapse nephrotic syndrome (IFRNS) and 11 were frequent relapse steroid dependant nephrotic syndrome(FRNS + SDNS).

Bronchial asthma and allergic dermatitis were found in about 63\% cases of both steroid resistant nephrotic syndrome (SRNS) and frequent relapse steroid dependant (FRNS+SDNS) group. Hypertension was found in higher number of patient in SRNS compared to SSNS (P>0.05) It was absent in IFRNS. Steroid contributed more than the disease process in producing hypertension $(P<0.01)$. Complement $C_{3}$ comparison among the group could not reach statistically significant level. Similarly, comparison of hematuria showed no difference among the groups but pyuria was higher in SRNS compared to IFRNS ( $P>0.05)$. UTI were found equally in all the groups.

Conclusion: Higher incidence of asthma, atopic dermatitis were noted in all the groups of idiopathic nephrotic syndrome (INS). $C_{3}$ was not found significantly low in INS. Persistent elevation of blood pressure is found in higher number of SRNS compared to SSNS and steroid contributed more than the disease process.
\end{abstract}

Key words: Complement $C_{3}$, asthma, hypertension, hematuria \& nephrotic syndrome.

\section{Introduction}

Nephrotic syndrome is characterized by massive proteinuria (urinary total protein $>1 \mathrm{gm} / \mathrm{m}^{2} /$ day or urinary spot protein creatinine ratio of $>200 \mathrm{mg} /$ mmol), hypoalbuminemia (serum albumin $<2.50 \mathrm{gm} /$ $\mathrm{dl}$ ), edema and hypercholesterolemia (serum cholesterol $>250 \mathrm{mg} / \mathrm{dl}$ ) ${ }^{1}$. Clinical and biochemical

1. Associate Professor, Department of Paediatric Nephrology, Bangabandhu Sheikh Mujib Medical University, Dhaka

2. Assistant Professor, Department of Paediatrics, Shaheed Suhrawardy Medial College, Dhaka

3. Medial Officer, National Institute of Health and Cancer Research Hospital, Dhaka

4. Professor, Department of Paediatric Nephrology, Bangabandhu Sheikh Mujib Medical University, Dhaka

5. Chairman \& Professor, Department of Paediatric Nephrology, Bangabandhu Sheikh Mujib Medical University, Dhaka

Correspondence: Dr. Ranjit Ranjan Roy features of nephrotic syndrome result from heavy proteinuria with consequent hypoalbuminemia and edema ${ }^{2}$.

Estimated annual incidence of nephrotic syndrome is 2-7 per 1, 00,000 children and the prevalence is $12-16$ per 100,000 . There is epidemiological evidence of higher incidence of nephrotic syndrome in children from South Asia and Africa ${ }^{2-5}$. Primary or idiopathic nephrotic syndrome is commonly seen $95 \%$ of patients ${ }^{6}, 80 \%$ of whom show histological features of minimal change nephrotic syndrome (MCNS) and have good prognosis ${ }^{7,8}$. Although recurrence is common in nephrotic syndrome, $90-95 \%$ of children with MCNS are responsive to steroid therapy with complete clinical biochemical remission and have 
excellent long term prognosis ${ }^{2,6,7,9}$. Steroid sensitive nephrotic syndrome (SSNS) comprises $80-90 \%$ of syndrome and rest $10-20 \%$ nephrotic syndrome is steroid resistant $(\mathrm{SRNS})^{10}$. Hypertension, hematuria, persistent hypocomplementimia, anemia, persistently raised serum creatinine and high cholesterol, unfavorable age ( $<2 \mathrm{yrs}$ and $>8 \mathrm{yrs}$ ) are regarded as bad prognostic features ${ }^{1,2,7,10}$. Asthma and other atopy are more common in NS 2,10 . So it is of importance to correlate the incidence of Asthma, hypertension, complement $\mathrm{c}_{3}$, and urinalysis in different types of Idiopathic nephrotic syndrome.

The objectives of the study were to compare the difference of Incidence of Asthma, Hypertension, complement $\mathrm{c}_{3}$ level and urinalysis in different types of Idiopathic nephrotic syndrome.

\section{Methods}

This observational prospective study of was carried out in the pediatric Nephrology unit of the department of pediatrics in the Bangabandhu Sheikh Mujib Medical University (BSMMU) from January 2003 to January 2005. The hospital is a tertiary referral hospital with diagnostic and treatment facilities.

A total of 480 children with primary nephrotic syndrome were admitted in BSMMU during the study period. Forty three (43) children were randomly selected who were aged 1-15 yrs. Among them, 19 had steroid resistant nephrotic syndrome (SRNS) leveled as group $B$ and 24 were steroid sensitive nephrotic syndrome (SSNS) leveled as group C, in SSNS group 11 children had FRNS +SDNS, (Group C1) and 13 had infrequent relapsing nephrotic syndrome IFRNS, (Group C2). Among the 19 children with SRNS, the histological reports on biopsy were mesangial proliferative glomerulonephritis (9 children), MCNS (3 children), focal segmental glomerulosclerosis (3children), membranoproliferative glomerulonephritis ( 2 children) and membranous glomerulonephritis (2 children).

Children below one year and above 15 years and those with congenital nephrotic syndrome, nephrotic syndrome secondary to systemic disease like systemic lupus erythromatosis, hepatitis B, Henoch Schonlein purpura, falciparum malaria, lymphoma or amylodosis were excluded from the study. Those with severe protein energy malnutrition or Down's syndrome were also excluded.

Parent and guardians of the enrolled children were informed about the purpose and procedure of the study and written consent was obtained at the enrollment. They were given the choice to withdraw from the study at any time during the course of the study. Data was collected by pre tested semi structured questionnaire. The study was approved by the Ethical Review committee of BSMMU.

\section{Laboratory investigations}

Urinary total protein (UTP) was measured by auto analyzer (RA 50 chemistry analyzer). Five (5) $\mathrm{ml}$ of venous blood sample was collected for estimation of serum complement $\mathrm{C} 3$ along with serum albumin, total protein, cholesterol, creatinine, blood urea and blood count including hemoglobin and ESR. Serum complement C3 was estimated by nephelometry method. Cut of value of low C3 level is $<770 \mathrm{mg} / \mathrm{dl}$.

Blood pressure was measured by aneroid B.P machine with appropriate size cuff. Hypertension was defined as blood pressure more than 95th centile for the corresponding age and sex.

Mantoux test (MT) and Bacillus calmette - Guernie (BCG) acceleration tests were performed when indicated. Antinuclear antibody (ANA) and anti DNA double stranded antibody (anti ds DNA) were measured by enzyme - linked immunosorbent assay (ELISA) in the children when indicated to rule out systemic disease. HbsAg was tested by screening and Elisa. Chest X-ray and Ultrasonography of the kidneys, ureters and bladder were performed for all the patients. Renal biopsy was done for SRNS patients.

\section{Study definition}

SSNS was defined as responding to steroid therapy within 4 weeks after initiation of the therapy ${ }^{2,3}$, IFRNS was defined as less than 4 relapses within one year or less the 2 relapses within 6 months after initial responsive episode and FRNS was defined as 4 or more than 4 relapses in one year and 2 or more than 2 relapses within six month after initial responsive episode. Remission was defined as protein free urine for 3 consecutive days and relapse was defined as proteinuria (urine albumin $3+$ or more) for 3 consecutive days after responsive episode $\mathrm{e}^{2,3}$. The occurrence of 2 consecutive relapses during alternate day prednisolone therapy or within 2 weeks of its discontinuation was defined as SDNS $^{2,3}$. No remission after 4 weeks of standard prednisolone therapy at $60 \mathrm{mg} / \mathrm{m} 2$ / day was defined as SRNS ${ }^{2,3}$. 
Asthma was defined as chronic inflammatory condition of the lung airways resulting in episodic airflow obstruction which is reversible by bronchodilator ${ }^{8}$.

Statistical analysis.

Statistical analysis was performed by using SPSS. Chi square test was used to compare between the groups.

\section{Results}

Table-I. Shows Bronchial asthma and allergic dermatitis were found high in all the groups. Table II.
Shows Hypertension was found in higher number of patient in SRNS compared to SSNS $(P>0.05)$ It was absent in IFRNS, Steroid contributed more than the disease process in producing hypertension $(P<0.01)$. $\mathrm{C}_{3}$ comparison among the group could not reach statistical significance (Table III). Similarly hematuria comparison shows no difference among the group, but pyuria was higher in SRNS compared to IFRNS $(P>0.05)$. UTI were found equally in all the groups (Table IV).

Table-I

Prevalence of wheeze and/or Allergic dermatitis in the steroid resistant and steroid sensitive groups.

\begin{tabular}{|c|c|c|c|c|c|c|}
\hline \multirow[t]{2}{*}{ Status } & \multicolumn{2}{|c|}{ Group B $(\mathrm{N}=19)$} & \multicolumn{2}{|c|}{ Group $C_{1}(\mathrm{~N}=11)$} & \multicolumn{2}{|c|}{ Group $C_{2}$} \\
\hline & No. & $(\%)$ & No. & $(\%)$ & No. & $(\%)$ \\
\hline Absent & 7 & $(36.8)$ & 4 & $(36.8)$ & 8 & $(61.5)$ \\
\hline Wheeze & 9 & $(47.4)$ & 5 & $(45.5)$ & 3 & $(23.1)$ \\
\hline Allergic dermatitis & 0 & 2 & $(18.2)$ & 2 & $(15.4)$ & \\
\hline Wheeze plus Allergic dermatitis & 3 & $(15.8)$ & 0 & 0 & & \\
\hline
\end{tabular}

$X^{2}=9.556, d f=6, P>0.10^{N S}$ (Chi-square test)

Table-II

Status of Blood pressure in the steroid resistant and the two steroid sensitive groups.

\begin{tabular}{|c|c|c|c|c|c|c|}
\hline \multirow[t]{2}{*}{ Status } & \multicolumn{2}{|c|}{ Group B (N=19) } & \multicolumn{2}{|c|}{ Group $C_{1}(N=11)$} & \multicolumn{2}{|c|}{ Group $C_{2}(N=13)$} \\
\hline & No. & (\%) & No. & $(\%)$ & No. & $(\%)$ \\
\hline Normotensive & 7 & $(36.8)$ & 7 & $(63.6)$ & 13 & $(100)$ \\
\hline Hypertensive by disease & 1 & (5.3) & 0 & & 0 & \\
\hline Hypertension by Prednisolone & 8 & $(42.1)$ & 3 & $(27.3)$ & 0 & \\
\hline Hypertension by disease plus Prednisolone & 3 & $(15.8)$ & 0 & & 0 & \\
\hline
\end{tabular}

$X^{2}=13.604, d f=6, P>0.05$ (Chi-square test)

Table-III

Status of complement $C_{3}$ in steroid resistant and steroid sensitive group.

\begin{tabular}{|c|c|c|c|c|c|c|}
\hline \multirow[t]{2}{*}{ C3 status } & \multicolumn{2}{|c|}{ Group B $(\mathrm{N}=19)$} & \multicolumn{2}{|c|}{ Group $C_{1}(\mathrm{~N}=11)$} & \multicolumn{2}{|c|}{ Group $\mathrm{C}_{2}(\mathrm{~N}=13)$} \\
\hline & No. & (\%) & No. & $(\%)$ & No. & $(\%)$ \\
\hline Normal & 13 & $(68.4)$ & 7 & $(63.6)$ & 12 & (92.3) \\
\hline Low & 6 & (31.6) & 4 & (36.4) & 1 & $(7.7)$ \\
\hline
\end{tabular}

$\mathrm{X}^{2}=3.216, \mathrm{df}=2, \mathrm{P}>0.10^{\mathrm{NS}}$ (Chi-square test) 
Table-IV

Urinalysis finding in the steroid resistant and steroid sensitive groups.

\begin{tabular}{|c|c|c|c|c|c|c|}
\hline \multirow[t]{2}{*}{ Status } & \multicolumn{2}{|c|}{ Group B (N=19) } & \multicolumn{2}{|c|}{ Group $C_{1}(N=11)$} & \multicolumn{2}{|c|}{ Group $C_{2}(N=13)$} \\
\hline & No. & $(\%)$ & No. & $(\%)$ & No. & $(\%)$ \\
\hline \multicolumn{7}{|c|}{ RBC (>5/ HPF) } \\
\hline Present & 12 & $(63.2)$ & 5 & $(45.5)$ & 5 & $(38.5)$ \\
\hline Absent & 7 & $(36.8)$ & 6 & $(54.5)$ & 8 & $(61.5)$ \\
\hline \multicolumn{7}{|c|}{$X^{2}=2.077, d f=2, P>0.10^{N S}$ (Chi-square test) } \\
\hline \multicolumn{7}{|c|}{ Pus Cell (>5/HPF) } \\
\hline Present & 15 & $(78.9)$ & 8 & $(72.7$ & 5 & $(38.5)$ \\
\hline Absent & 4 & $(21.1)$ & 3 & $(27.3)$ & 8 & $(61.5)$ \\
\hline \multicolumn{7}{|c|}{$X^{2}=5.947, d f=2, P>0.05^{N S}$ (Chi-square test) } \\
\hline \multicolumn{7}{|c|}{ Growth in urine $\left(>10^{5} \mathrm{cc}\right)$} \\
\hline Present & 4 & $(21.1)$ & 2 & $(18.2)$ & 4 & (30.8) \\
\hline Absent & 15 & (78.9) & 9 & (81.8) & 9 & (69.2) \\
\hline
\end{tabular}

$\mathrm{X}^{2}=.622, \mathrm{df}=2, \mathrm{P}>0.50^{\mathrm{NS}}$ (Chi-square test)

\section{Discussion}

Ninety five percent of nephrotic syndromes are idiopathic (INS) and $80 \%$ of idiopathic childhood nephrotic syndromes are MCNS. Presence of hypertension, gross hematuria and impaired renal function indicate significant glomerular lesion ${ }^{9,11}$.

In our study more number of SRNS and FRNS + SDNS had low $\mathrm{C}_{3}$ than IFRNS though the level could not reach statistical significance. Persistent low $\mathrm{C}_{3}$ is a bad prognostic finding 2, 10, 12. But chan et al ${ }_{13,14}$ observed increased $C_{3}$ probably due to increased hepatic synthesis correlate significantly with serum cholesterol irrespective of underlying renal histology. Abinsola et al ${ }^{15}$ also recorded higher $\mathrm{C}_{3}$ and $\mathrm{C}_{4}$ in patients with active nephrotic syndrome. High incidence of atopy, asthma of our study subjects was consistent with other studies and text books views ${ }^{2}$, 10, 16, 17 .

Hypertension in our SRNS subjects were in corollary with other studies and textbooks views $2,10,13$ Persistent elevation of blood pressure is unusual of MCNS and should raise the suspicion of other form of glomerulopathy and have bad prognosis ${ }^{13}$. In our study oral steroid had contributed hypertension in small number of frequent relapse steroid dependant (FRNS + SDNS) patients but intravenous methyl prednisolone had contributed hypertension in large number of our steroid resistant nephrotic syndrome (SRNS) subjects.

Srivastava observed proteinuria with associated microscopic hematuria were more likely a manifestation of significant renal lesion 18 . Constantinescu ${ }^{19}$ and Srivastava observed poor association with hematuria. MCNS have occasional gross hematuria ${ }^{20}$, and transient hypertension ${ }^{13}$.

Begum observed hypertension, hematuria and renal impairment significantly higher in SRNS ${ }^{21 .}$

\section{Conclusion}

Higher incidence of asthma, atopic dermatitis were noted in all the groups of INS. $\mathrm{C}_{3}$ was not found significantly low in INS. Persistent elevation of blood pressure is unusual of MCNS and should raise the suspicion of other forms of glomerulopathy and have bad prognosis. Steroid contributed more than the disease process in producing hypertension. In urinalysis pyuria was found higher in SRNS compared to IFRNS but other urinary finding did not differ significantly between various groups of INS.

Group B = Steroid resistant nephrotic syndrome Group $C_{1}=$ FRNS+SDNS (Steroid sensitive) Group $C_{2}=$ IFRNS (Steroid sensitive) FRNS = Frequent relapsing nephrotic syndrome IFRNS = Infrequent relapsing nephrotic syndrome SDNS = Steroid dependent nephrotic syndrome 


\section{References:}

1. ISKDC (International study of Kidney disease in children). Nephrotic Syndrome in children:Prediction of histopathology from clinical and laboratory characteristics at time of diagnosis. Kidney Int.1978; 13:159-165.

2. Srivastva RN, Bagga A. Nephrotic Syndrome. In: Srivastava RN, Bagga A, edns. Pediatric Nephrology, $4^{\text {th }}$ edn, New Delhi: Jaypee Brothers, Medical Publishers(P) Ltd,2005: p. 161-167.

3. Rahman A MB, Aikhonbare HA, Babaoye FA, Sathiakumar N, Narayana PT. Clinicopathological features of childhood Nephrotic Syndrome in Northen Nigeria. QJ Med 1990; 75: 563-576.

4. Eddy AA, Symons JM, Nephrotic Syndrome in childhood. Lancet 2003; 362: 629-639.

5. McKinney PA, Feltbower RG, Brocklebank JT, Fitzpatrick MM. Time trends and ethnic patterns of childhood Nephrotic Syndrome in Yorkshire. UK. Pediatric Nephrology 2001; 16: 1040-1044

6. Churg S, Habib R, White RH. Pathology of Nephrotic Syndrome in children. A report for the International study of Kidney disease in children. Lancet 1970; 1: 1299-1302.

7. Salcedo JR, Thabet MA, Latta K, Chan JC. Nephrosis in childhood. Nephron1995; 71: 375385.

8. Behrman RE, Kliegman RM, Jenson HB. Nephrotic Syndrome: Nelson Text book of Pediatrics, $17^{\text {th }}$ ed. Philadelphia: WB Saunders Company. 2004:1753-1757.

9. ISKDC (International study of Kidney disease in children). The Primary Nephrotic Syndrome in children. Identification of patients with minimal change Nephrotic Syndrome from initial response to prednisolone. A report of the International study of Kidney disease in children. J Pediatric 1981; 98: 561-564.

10. Niaudet P. Steroid sensitive idiopathic Nephrotic Syndrome in children. In : avner ED, harmol WE, Niaudet P, eds. Pediatric Nephrology, $5^{\text {th }}$ ed. Philadelphia: Lippincott Williams and Wilkins, 2004: p. 543-553.
11. White RHR, Glasgow EF, Mills RI, Clinico pathological study of Nephrotic Syndrome in childhood. Lancet 1970; 1,27: 1353-1359.

12. Kliegman RM, Behrman RE, Jenson HB, Stanton BF. Nephrotic Syndrome, Nelson's Text book of Pediatrics, $18^{\text {th }}$ ed, vol-2. Saunders, Philadelphia: 2008: p. 2190-95.

13. Haycock G. The child with idiopathic Nephrotic Syndrome In: Clinical Pediatric Nephrology. 3rd edition. Oxford University press. New York 2003.

14. Chan MK, Chan KW, Jone B, Immunoglobulin (IgG, IgA, IgM, IgE and complement component $\left(C_{3}, C_{4}\right)$ in Nephrotic Syndrome due to minimal change and other forms of glomerulonephritis: a clue to steroid therapy. Nephron 1987; 7: 12530.

15. Abinsola A, Mbenefo Co, Iyun AB. Serum Immunoglobulin and complements in Nephrotic Syndrome. Afr J Med Sci 1984,13:41-6.

16. Chen G, Seah CC, Yap HK, Goh DYT, Lee BW. Immunoglobulin and IgG subclasses in Asian Children with Bronchial Asthma. Ann Trop Pediatric 1995; 15: 279-84.

17. Yap HK, Han EJ, Heng CK, Gong WK. Risk factors for steroid dependence in children with idiopathic Nephrotic Syndrome. Pediatric Nephrol 2001; 16: 1049-52.

18. Srivastva RN. Isolated asymptomatic Proteinuria. Symposium on nephrology-1. Indian J Pediatrics 2002; 69:1063-68.

19. Constinescu AR, Shah HB, Foote EF, Weiss LS. Predicting first year relapses in children with Nephrotic Syndrome, Pediatrics.2000, 105(301):492-5.

20. Butani L. Gross hematuria in minimal change Nephrotic Syndrome. Pediatric Nephrology 2006; 21: 1783.

21. Begum A. Clinicopathological correlation and Steroid sensitivity pattern of children with Nephrotic Syndrome having atypical presentation. Thesis BSMMU.2004.P.42. 